\title{
Pulverized coal gasification with steam and flue gas
}

\author{
Robert Zarzycki ${ }^{1, *}$ \\ ${ }^{1}$ Czestochowa University of Technology, Department of Energy Engineering, Brzeźnicka 60A, 42-201 Częstochowa, Poland
}

\begin{abstract}
The study presents the concept and numerical calculations of the coal dust gasification in the entrained flow reactor with power of $16 \mathrm{MW}_{\mathrm{t}}$. The gasification process in the reactor can be performed in the atmosphere of $\mathrm{O}_{2}, \mathrm{CO}_{2}$ and $\mathrm{H}_{2} \mathrm{O}$. The combustible gases obtained during gasification are composed mainly of $\mathrm{CO}$ and $\mathrm{H}_{2}$ and can be used to feed pulverized coal-fired boilers. Integration of the reactor (reactors) for coal dust gasification with the pulverized coal-fired boiler allows for improved flexibility, especially in the range of low loads if stabilization of coal dust combustion in pulverized-fuel burners or support for their work with ignition burners fed with gas or light fuel oil is necessary. The concept of the gasification reactor assumes strong eddy motion of the coal dust, which substantially allows for elongation of the time of fuel remaining in the reactor and obtaining a high reaction level. The concept of the entrained flow reactor presented in this study and the results of numerical calculations can be helpful for development of the devices with greater powers which in the nearest future should be integrated in the systems of pulverized coal-fired boilers in order to reduce their minimum load without using the ignition burners.
\end{abstract}

\section{Introduction}

Ensuring uninterrupted supplies of electricity and heat is mainly obtained in energy processes by combustion of fossil fuels (hard and brown coal, petroleum and natural gas). With the development of nuclear energy and renewable energy technologies, the demand for nonrenewable fuels is gradually decreasing. Despite numerous benefits, such as low costs of electricity production, low level of waste and insignificant demand for fuel and huge resources of the fuel, nuclear energy has also some drawbacks, such as high costs of construction of nuclear power plants, generation of waste that is very dangerous to humans and the environment, and risk of failures. The risk of failures, terrorist attack and nuclear disasters that have occurred (Fukushima, Chernobyl) substantially limited the trust to the nuclear energy. Many countries with nuclear power plants plan to shut them down and return to the use of fossil fuels.

A dynamic development of renewable energy based mainly on the use of wind power allows for limitation of the use of fossil fuels. The major problem with renewable energy is the lack of stability of energy supplies, whose production depends substantially on atmospheric conditions (wind). In such cases, conventional power plants (coal-fired) have to be prepared for the replenishment of the electricity deficit in the electric power system. In many cases, operation of high-performance power units with minimal power (minimum load) or temporary shutting down the units is necessary due to the surplus of electricity in the electric power system.

Therefore, it is critical that modern power units are characterized by a low value of minimum load and high dynamics of changes in the load [1]. Technology of fluidized-bed furnaces allows for operation of the unit in the range of $40-100 \%$, with minimal power of the unit limited by the necessity of maintaining the fluidization process inside the furnace [2]. In the case of pulverizedfuel boilers, minimal load depends on the design and specifications of the boiler and ranges from $40 \%$ to $60 \%$. This is connected with stabilization of the coal dust process at low boiler loads (lower temperatures inside the combustion chamber) and ensuring the minimal water circulation rate in the radiant tubes of the boiler. Reduction of the pulverized-fuel boiler power below the minimal level requires starting the ignition burners in order to ensure a stable coal dust combustion process. The use of the ignition burners fuelled by light fuel oil, mazut or natural gas increases the costs of steam power unit operation and emissions of harmful substances.

The increase in flexibility of steam power units equipped in pulverized-fuel boilers can be achieved by replacing ignition fuels (fuel oil, mazut, natural gas) with the gas generated during coal gasification. This solution allows for utilization of the basic fuel in the power plant (hard coal and brown coal) for production of the syngas. Installation of burners in pulverized-fuel boilers fuelled with synthesis gas allows for stabilization of the combustion of coal dust at low loads of the power unit and maintaining the boiler in the state of hot reserve using gas burners fuelled by synthesis gas. The use of burners fuelled with synthesis gas during power unit start up is also possible (replacing the ignition burners). This proposal of the use of synthesis gas allows for limitation of consumption of expensive ignition fuels, especially if the steam power unit has to be operated over the broad range of changes in the load.

\footnotetext{
*orresponding author: zarzycki@is.pcz.czest.pl
} 
The achievement of such a goal requires a reactor design that ensures control over the coal gasification process. In the case of actual power facilities, it is important that unit power of the reactor should allow for replacing of one or several ignition burners.

The study presents the concept and numerical computations of the reactor operation to perform coal gasification process in the atmosphere of recirculating flue gas and water steam.

\section{The concept of reactor for coal gasification}

Coal gasification process can be performed using one of the three types of reactors (Fig. 1):

-moving bed reactors;

-fluidized-bed reactors;

-entrained-flow reactors.

Moving bed reactors (Fig. 1a) (Lurgi) are designed to gasify solid fuels with grain size ranging from 5 to $80 \mathrm{~mm}$. Time of fuel gasification process depends on the gasification medium (oxygen, air, water steam) and pressure at which the process is performed (environmental pressure, overpressure) and ranges from several minutes to several hours. The most popular reactors include counter-current flow of fuel and gasifying agent with their power reaching $350 \mathrm{MW}_{\mathrm{t}}$. Heat needed for the gasification process originates from partial combustion of the charge. Gasification in a stationary bed requires fuel and low agglomerating capacity of coal. The main problem connected with operation of moving bed reactors is the disposal of fragmented fuel and liquid hydrocarbons [4-9].

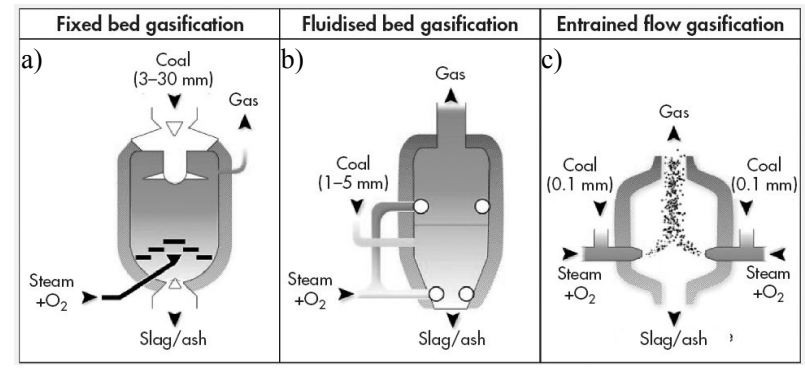

Fig. 1. Gasification process for coal [3].

In fluidized-bed reactors (Fig. 1b) (Winkler), it is necessary to prepare fuel through its fragmentation in the range of 0.5-6 $\mathrm{mm}$ in order to ensure efficient fluidizing. Time of fuel remaining in the reactor ranges from 10 to $100 \mathrm{~s}$ while its temperature has to be lower than the softening point of the ash contained in the coal. Unit powers of fluidized-bed reactors reach $700 \mathrm{MW}_{\mathrm{t}}$. Gasifying agents include oxygen, air and water steam introduced from the bottom. The major problem with operation of fluidized-bed reactors is poor conversion of the $\mathrm{C}$ element resulting from low process temperatures limited by the ash softening point [4-9].

In entrained flow reactors (Fig. 1c) (KoppersTotzek), fragmented coal is transported in the streams of the gasifying agent (oxygen and water steam mixture).
With fragmentation of fuel to grains of below $0.1 \mathrm{~mm}$ and the temperature during the gasification process ranging from $1200-1600^{\circ} \mathrm{C}$, time of fuel grain remaining amounts to several seconds, which allows for reaching high unit gas efficiency and reactor power of $700 \mathrm{MW}_{\mathrm{t}}$. One benefit of this type of generators is the opportunity to use caking coals as raw materials and no temperature limits caused by ash composition. The main problems connected with operation of entrained flow reactors is to ensure continuous supply of the gasifying agent and fuel with the specific ratio and cooling of the gas generated during gasification [4-9].

The biggest potential connected with the achievement of high efficiencies of synthesis gas, rate of changes in efficiency and opportunity to control coal gasification process is observed for entrained flow reactors for coal gasification [9]. They allow for coal dust gasification in the atmosphere of recirculated flue gas and in the presence of water steam. Ash vitrification can also be performed [10-16].

Fig. 2 presents a design of entrained-flow reactor for coal gasification with power output of $16 \mathrm{MW}_{\mathrm{t}}$. The reactor is composed of seven main components presented in Fig. 2. The $\mathbf{C 1}$ dome contains one burner nozzle with diameter of $50 \mathrm{~mm}$ and four nozzles for supplying gases with specific content to the reactor. Below the $\mathbf{C 1}$ dome there is $\mathbf{C 2}$ with diameter of $2 \mathrm{~m}$, composed of ten cylindrical segments with the height of $0.5 \mathrm{~m}$ each. Each segment has eight nozzles with diameter of $50 \mathrm{~mm}$ at the angle of $45^{\circ}$. The nozzles were installed so that their distance from the symmetry axis of the chamber $\mathbf{C 2}$ in each lower segment is incremented by $50 \mathrm{~mm}$. This design allows for a strong eddy motion of the gas and fuel supplied to $\mathbf{C 2}$. Below the $\mathbf{C 2}$ chamber there is the $\mathbf{C 3}$ chamber with the height of $1 \mathrm{~m}$ and reducing diameter to $1.8 \mathrm{~m}$, where three levels of nozzles with diameter of $50 \mathrm{~mm}$ are located. Each level contains eight nozzles (distributed every $90^{\circ}$ ). This system of nozzles ensures a strong eddy motion of the gas and fuel. Below the chamber $\mathbf{C} 3$ there is the $\mathbf{C 4}$ chamber with special design, composed of ten segments with the height of $0.5 \mathrm{~m}$ each. Each segment has four levels of nozzles distributed every $90^{\circ}$ with diameter of $50 \mathrm{~mm}$. Side walls of each segment in the $\mathbf{C} \mathbf{4}$ chamber were shaped so that the nozzles are installed tangentially to the chamber walls. The nozzles are also inclined at the angle of $5^{\circ}$.

The chamber $\mathbf{C 5}$, composed of two truncated cones is located in the lower part, with a step between each other aimed to extend the time of fuel remaining in the boiler. Nozzles are tangentially installed in the side walls of the C5 chamber, at five steps, distributed every $90^{\circ}$. Below them there is the $\mathbf{C 6}$ chamber, cylindrically-shaped, with diameter of $3 \mathrm{~m}$ and tangentially installed channel used to discharge gases from the reactor. A plunger is installed inside the $\mathbf{C 6}$ chamber. Below this point there is the $\mathbf{C} 7$ chamber composed of two truncated cones and a cylindrical chamber. The chambers $\mathbf{C 6}$ and $\mathbf{C 7}$ act as a cyclone that allows for separation of solid particles from the gas generated in the reactor. 
a)

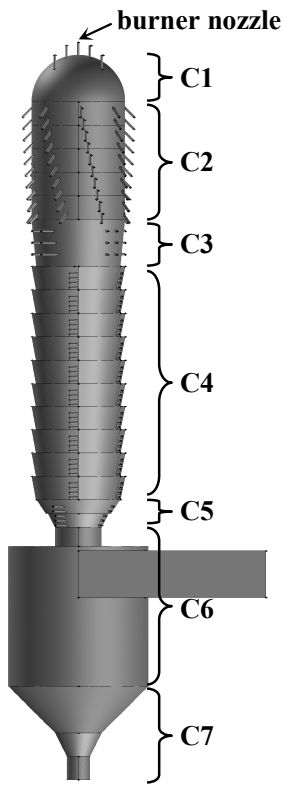

c)

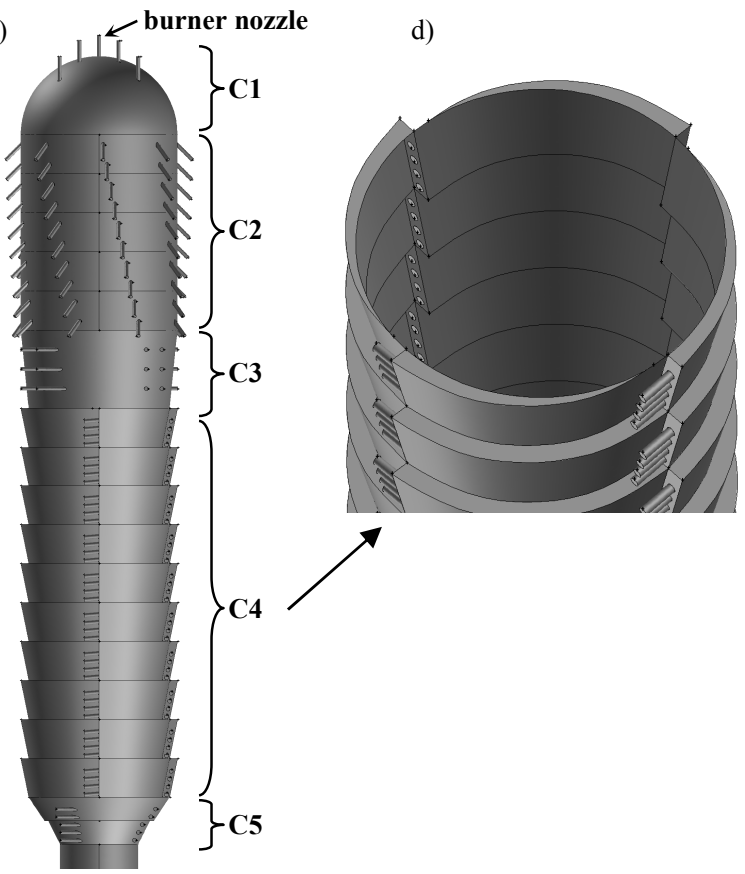

Fig. 2. Entrained flow reactor for coal gasification.

\section{Numerical analysis of coal dust gasification process}

Geometry and the grid used for computation of the coal dust gasification reactor (Fig. 2) was developed using the GAMBIT software. The ANSYS FLUENT 14 software was used to compute coal dust gasification process.

Calculations of coal dust and gas flow were performed using the Reynolds Stress turbulence model. Modelling of flow of coal dust was based on the Discrete Phase Model, whereas coal dust combustion was performed using Species Transport model, which allows for modelling chemical reactions both in the solid phase and gaseous phase [17-22]. The Single-Rate fuel devolatilization model was employed. Calculations were based on the radiation model termed Discrete Ordinate
(DO). A numerical model of the process allows for computation of combustion, fuel devolatilization and fuel gasification in the atmosphere of air, $\mathrm{O}_{2}, \mathrm{CO}_{2}$ and water vapour.

Calculations of coal dust gasification process for the dust with mean size of $0.25 \mathrm{~mm}$ were carried out for coal dust with physicochemical parameters as presented in Table 1.

Table 1. Results of technical and elemental analysis of the fuel used for simulations (dry state)

\begin{tabular}{|c|c|c|c|c|c|c|c|c|}
\hline $\begin{array}{c}\text { M } \\
{[\%]}\end{array}$ & $\begin{array}{c}\mathbf{A} \\
{[\%]}\end{array}$ & $\begin{array}{l}\text { VM } \\
{[\%]} \\
\end{array}$ & $\begin{array}{c}\text { FC } \\
{[\%]}\end{array}$ & $\begin{array}{c}\mathrm{C} \\
{[\%]}\end{array}$ & $\begin{array}{c}\mathbf{H} \\
{[\%]}\end{array}$ & $\begin{array}{c}\mathbf{N} \\
{[\%]}\end{array}$ & $\begin{array}{c}\mathbf{0} \\
{[\%]}\end{array}$ & $\begin{array}{c}\text { HHV } \\
{[\mathrm{MJ} / \mathrm{kg}]}\end{array}$ \\
\hline 5 & 5 & 45 & 45 & 85 & 10 & 1 & 4 & 24.7 \\
\hline \multirow{2}{*}{\multicolumn{9}{|c|}{$\begin{array}{l}\mathbf{A} \text { - ash } \\
\text { M - moisture }\end{array}$}} \\
\hline & & & & & & & & \\
\hline VM - & olatile & ttter & & & & & & \\
\hline $\begin{array}{l}\text { FC - fi } \\
\text { HHV }\end{array}$ & $\begin{array}{l}\text { ed ca } \\
\text { iighe }\end{array}$ & & & & & & & \\
\hline
\end{tabular}

For simplification purposes, it was adopted that the fuel does not contain sulphur. Reaction rate constants were derived from the studies $[17,18]$.

Calculations for combustion and gasification of coal dust were described with seven reactions:

- Reaction of volatile matter (VM) combustion

$$
\mathrm{VM}=\mathrm{C}_{1.74} \mathrm{H}_{5.95} \mathrm{O}_{0.15} \mathrm{~N}_{0.0428}
$$

$\mathrm{VM}+2.28 \mathrm{O}_{2}=1.74 \mathrm{CO}+2.79 \mathrm{H}_{2} \mathrm{O}+0.0214 \mathrm{~N}_{2}(1)$

- Reaction of oxidation of carbon oxide

$$
\mathrm{CO}+0.5 \mathrm{O}_{2}=\mathrm{CO}_{2}
$$

- Reaction of oxidation of fixed carbon (FC)

- Boudouard's reaction

$$
\mathrm{C}_{(\mathrm{s})}+0.5 \mathrm{O}_{2}=\mathrm{CO}
$$

$$
\mathrm{C}_{(\mathrm{s})}+\mathrm{CO}_{2}=2 \mathrm{CO}
$$

- Synthesis of water gas

$$
\mathrm{C}_{(\mathrm{s})}+\mathrm{H}_{2} \mathrm{O}=\mathrm{CO}+\mathrm{H}_{2}
$$

- Hydrogen oxidation reaction

$$
\mathrm{H}_{2}+0.5 \mathrm{O}_{2}=\mathrm{H}_{2} \mathrm{O}
$$

- Methane oxidation reaction

$$
\mathrm{CH}_{4}+2 \mathrm{O}_{2}=\mathrm{CO}_{2}+2 \mathrm{H}_{2} \mathrm{O}
$$

Numerical computations were performed for two variants:

- V1 - gasification in the atmosphere of $\mathrm{O}_{2} / \mathrm{CO}_{2}$,

- V2 - gasification in the atmosphere of $\mathrm{O}_{2} / \mathrm{H}_{2} \mathrm{O}$.

In both cases ( V1 and V2), the conditions of fuelling the $\mathbf{C} 1$ and $\mathbf{C} 2$ chambers were identical. The burner located in the $\mathbf{C 1}$ chamber was fuelled by the $\mathrm{O}_{2} / \mathrm{CH}_{4}$ mixture at the rate of $15 \mathrm{~m} / \mathrm{s}$ with volumetric ratios of $80 / 20 \%$. The nozzles were fuelled by the mixture of $\mathrm{O}_{2} / \mathrm{CO}_{2}$ at the speed of $5 \mathrm{~m} / \mathrm{s}$ with volumetric ratios of $80 / 20 \%$. The $\mathbf{C 2}$ chamber was fuelled by the $\mathrm{O}_{2} / \mathrm{CO}_{2}$ mixture with the speed of $5 \mathrm{~m} / \mathrm{s}$, with volumetric ratio of $70 / 30 \%$. With this gas, coal dust was also supplied to the C2 chamber. Total flux of the coal dust was $0.65 \mathrm{~kg} / \mathrm{s}$, whereas $0.11 \mathrm{~kg} / \mathrm{s}$ was supplied at the highest step, and reduced for each step down by $0.01 \mathrm{~kg} / \mathrm{s}$. The lowest step of the $\mathbf{C 2}$ chamber was fuelled at a rate of $0.02 \mathrm{~kg} / \mathrm{s}$.

For the $\mathbf{V 1}$ variant, the $\mathbf{C} \mathbf{3}$ chamber was fuelled with the $\mathrm{O}_{2} / \mathrm{CO}_{2}$ mixture with the rate of $7 \mathrm{~m} / \mathrm{s}$ and volumetric ratio of $50 / 50 \%$. The $\mathbf{C 4}$ chamber was fuelled with the gas with every second step of nozzles with the parameters similar to the C3. The chamber C5 was 
fuelled by the $\mathrm{O}_{2} / \mathrm{CO}_{2}$ mixture at a rate of $10 \mathrm{~m} / \mathrm{s}$, with volumetric ratio of $50 / 50 \%$ only in the upper cone.

The difference between $\mathbf{V 1}$ and $\mathbf{V} \mathbf{2}$ variants is connected with replacement of the carbon dioxide supplied to C3, C4 and C4 (variant V1) with water steam (variant V2).

Temperature of gas mixtures supplied with nozzles to the reactor was identical for both cases $(\mathbf{V} \mathbf{1}$ and $\mathbf{V} \mathbf{2})$, i.e. $300^{\circ} \mathrm{C}$.

The results of the gasification process in the $\mathrm{O}_{2} / \mathrm{CO}_{2}$ atmosphere (variant V1) are presented in Fig. 3. Fig. 3a presents distribution of the peripheral gas rate in the vertical cross-section resulting from the supply of the gas with tangentially designed nozzles. The highest levels of the peripheral component are observed near the reactor walls in the chamber $\mathbf{C 4}$ and C5. Concentration of the fuel supplied to the reactor with nozzles installed in the C2 chamber is presented in Figs. 3b, 3c and 3d. With the nozzles installed in the $\mathbf{C 2}$ chambers at the angle of $45^{\circ}$ and their shift with respect to axes at individual steps, the fuel supplied to the chamber is decomposed in the form of the rings observed inside the $\mathbf{C} \mathbf{2}$ chamber along its height (Fig. 3b, Fig. 3c).

a) $V_{x}[m / s]$

$$
\begin{aligned}
& 12 \\
& 11 \\
& 10 \\
& 8 \\
& 7 \\
& 6 \\
& 5 \\
& 4 \\
& 2 \\
& 1 \\
& 0 \\
& -1 \\
& -2 \\
& -4 \\
& -5 \\
& -6 \\
& -7 \\
& -7 \\
& -10 \\
& -11 \\
& -12
\end{aligned}
$$

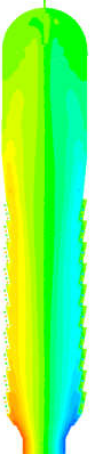

b) DPM conc. $\left[\mathrm{kg} / \mathrm{m}^{3}\right]$

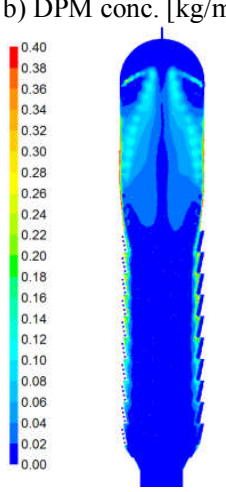

$\begin{array}{ll}\text { d) DPM conc. }\left[\mathrm{kg} / \mathrm{m}^{3}\right] & \text { e) } \mathrm{O}_{2}[-]\end{array}$
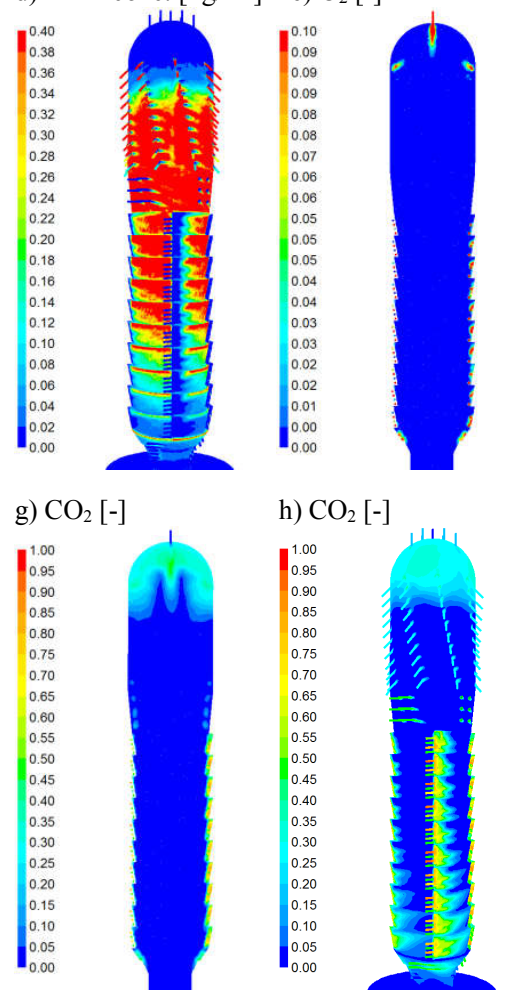

j) Temp. $[\mathrm{K}]$

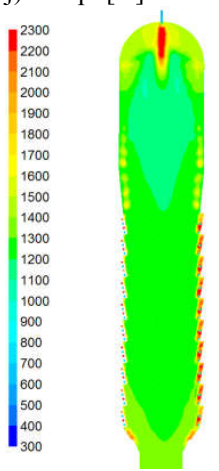

m) VM [-]

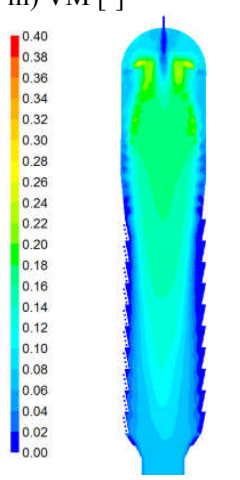

p) $\mathrm{H}_{2}[-]$
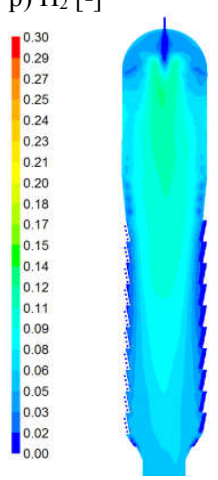

k) Temp. [K]
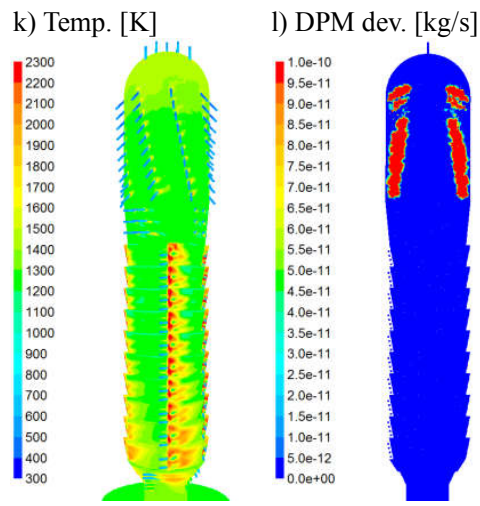

n) DPM burnout $[\mathrm{kg} / \mathrm{s}]$ o) $\mathrm{CO}[-]$
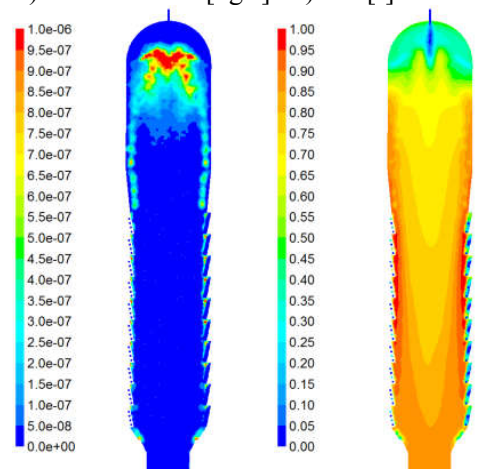

q) $\mathrm{CH}_{4}[-]$

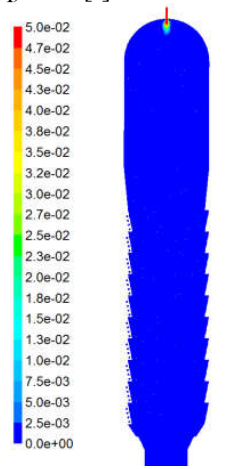

r) $\mathrm{V}_{\mathrm{z}}[-]$

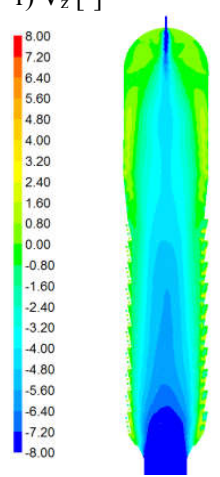

Fig. 3. Distribution of selected process values (V1):

a) peripheral velocity component, b) fuel concentration in the vertical cross-section, c) fuel concentration, d) fuel concentration on the furnace walls, e) $\mathrm{O}_{2}$ concentration, f) $\mathrm{O}_{2}$ concentration on the furnace walls, g) $\mathrm{CO}_{2}$ concentration,

h) $\mathrm{CO}_{2}$ concentration on the furnace walls, g) $\mathrm{H}_{2} \mathrm{O}$ concentration, j) temperature distribution in the vertical crosssection, k) temperature distribution near furnace walls,

1) devolatilization rate distribution in the vertical cross-section, $\mathrm{m}$ ) volatile matter concentration, $\mathrm{n}$ ) fuel burning rate, o) $\mathrm{CO}$ concentration, p) $\mathrm{H}_{2}$ concentration, q) $\mathrm{CH}_{4}$ concentration, r) vertical velocity component.

With the effect of the centrifugal force caused by swirling gas (Fig. 3a), the fuel supplied to the C2 chamber is transported near the reactor walls (Fig. 3c). The gas supplied tangentially to the $\mathbf{C 3}$ and $\mathbf{C 4}$ chambers at a rate of $7 \mathrm{~m} / \mathrm{s}$ increases the value of the centrifugal force and, consequently, the fuel remains only near the reactor walls.

This phenomenon is very beneficial due to the extension of time of fuel remaining near the specifically shaped walls of the $\mathbf{C} \mathbf{4}$ chamber, whereas the gasifying agent is supplied only near the walls, which allows for 
gasification of the fuel in this area. The special shape of the $\mathbf{C} 4$ chamber helps intensify mixing of gas and the fuel swirling inside the reactor (Fig. 4), allowing for an efficient gasification process. Process conditions were set so that fuel concentration at the outlet from the $\mathbf{C 5}$ chamber was equal zero. This means that total stream of the fuel supplied to the reactor is gasified in its interior. In the analysed variant, the gasification agents were $\mathrm{O}_{2}$ and $\mathrm{CO}_{2}$, with distributions presented in Figs. 3e, $3 \mathrm{f}, 3 \mathrm{~g}$ and $3 \mathrm{~h}$. Distributions of $\mathrm{O}_{2}$ concentration in the vertical cross-section of the reactor (Fig. 3e) show substoichiometric conditions inside the reactor whereas elevated $\mathrm{O}_{2}$ concentration is observed only near the nozzles that fuel the $\mathrm{C}_{4}$ chamber. Analysis of $\mathrm{CO}_{2}$ distribution reveals elevated concentration of this gas in the $\mathbf{C} \mathbf{1}$ chamber and in the upper part of the $\mathbf{C} \mathbf{2}$ chamber. This is connected with the necessity of combustion (reaction 1) of a specific amount of gases generated through fuel devolatilization (Fig. 31, 3m) due to the necessity of ensuring heat for the performance of endothermic processes of coal gasification. Furthermore, $\mathrm{CO}_{2}$ is generated through combustion of the $\mathrm{O}_{2} / \mathrm{CH}_{4}$ mixture supplied with the burner nozzle. Due to the gasification process (reaction 4), the $\mathrm{CO}_{2}$ concentration is noticeably reduced, and in the central part of the $\mathbf{C 2}$ chamber, it equals nearly zero. $\mathrm{CO}_{2}$ concentration near reactor walls is presented in Fig. $3 \mathrm{~h}$. Similar to $\mathrm{O}_{2}$, its elevated concentration is observed only near the nozzles that supply the $\mathrm{O}_{2} / \mathrm{CO}_{2}$ mixture. This suggests intensive processes of mixing and coal gasification (reaction 4). Figure 3i illustrates $\mathrm{H}_{2} \mathrm{O}$ concentration. Presence of $\mathrm{H}_{2} \mathrm{O}$ is due to the combustion of the $\mathrm{O}_{2} / \mathrm{CH}_{4}$ mixture (reaction 7) in the burner installed in the $\mathbf{C 1}$ chamber and humidity contained in the fuel. Similar to $\mathrm{CO}_{2}$ distribution, $\mathrm{H}_{2} \mathrm{O}$ concentration was significantly reduced in the initial part of the the $\mathbf{C 2}$ chamber, which suggests the gasification process (reaction 5) using water steam, which results in the increase in $\mathrm{H}_{2}$ concentration (Fig. 3p).

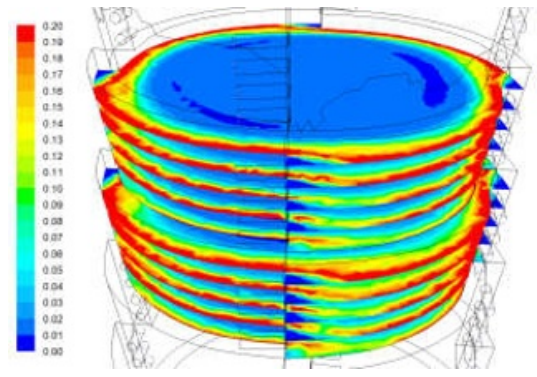

Fig. 4. Distribution of fuel concentration in C4 (V1).

Figures $3 \mathrm{j}$ and $3 \mathrm{k}$ illustrate distributions of temperature inside the reactor and near its walls, respectively. The highest temperature values are observed near the burner (chamber C1) and near the walls of the $\mathbf{C} 4$ chamber. Gasification processes require ensuring adequate amount of heat to perform them and maintain optimal thermal conditions due to the pattern of coal gasification reaction. Mean temperatures in the reactor are around $1000-1200^{\circ} \mathrm{C}$ near the reactor walls (C4 chamber). In the locations where the $\mathrm{O}_{2} / \mathrm{CO}_{2}$ mixture is supplied, local temperature reaches the level near $2000^{\circ} \mathrm{C}$. This allows for a fast heating of the fuel in this zone and intensification of the gasification processes (reactions 3, 4 and 5). Local temperature of $2000^{\circ} \mathrm{C}$ also allows for vitrification of ash remaining after the gasification process. It is possible in this case to discharge the molten ash with the combustible gases obtained through gasification to the C6 and C7 chambers. The fuel supplied to the $\mathbf{C 2}$ chamber is devolatilized, which can be observed in Fig. 31, which illustrates fuel devolatilization rate. This results in the distribution of concentration of volatile matter (VM), as presented in Fig. $3 \mathrm{~m}$.

The highest VM concentration occurs in the upper part of the $\mathbf{C 2}$ chamber and is insignificantly reduced with the flow towards the $\mathbf{C 4}$ and $\mathbf{C 5}$ chambers. Near the reactor walls, VM concentration is noticeably decreased, which results from partial combustion of volatile matter (reaction 1) and dilution with gasification products (reaction 3, 4 and 5) generated near the reactor walls. The parameter which reflects the rate of fuel conversion in the reactor is presented in Fig. 3n. The highest fuel conversion rates are observed near the burner and near the locations of supply of the gasifying agent $\left(\mathrm{O}_{2} / \mathrm{CO}_{2}\right)$. The main product of the gasification process for the $\mathbf{V 1}$ is $\mathrm{CO}$, whose distribution is presented in Fig. 3o. Near the burner nozzle (C1 chamber), $\mathrm{CO}$ concentration is ca. $20-40 \%$, whereas down the stream, the CO content in the reactor axis rises noticeably to the level of $60-80 \%$. The highest values of the $\mathrm{CO}$ concentrations are observed near the wall of the $\mathbf{C} \mathbf{3}$ and $\mathbf{C} \mathbf{4}$ chambers, with elevated fuel concentration (see Figs. 3b, 3c, 3d) and places where the gasification factor of $\mathrm{O}_{2} / \mathrm{CO}_{2}$ is supplied. The other gasification product is $\mathrm{H}_{2}$, with its distribution presented in Fig. 3p. Presence of this gas component results on the one hand from gasification of coal dust in the presence of water steam generated due to combustion of $\mathrm{CH}_{4}$ and humidity contained in fuel. Furthermore, $\mathrm{H}_{2}$ is partially obtained from combustion of a part of volatile matter (reaction 1) and then gasification of fuels in the generated stream of water vapour (reaction 5). Due to the superstoichiometric conditions of $\mathrm{O}_{2} / \mathrm{CH}_{4}$ burner operation, methane supplied to the do reactor is quickly burnt (Fig. 3q). Figure $3 r$ presents the vertical component of gas velocity in the reactor. With adequate installation of the nozzles in side walls of the reactor, it is possible to obtain flow of gas towards the $\mathbf{C} \mathbf{1}$ chamber near the walls, whereas in the reactor axis, the flow is noticeably oriented towards the C5 chamber. This organization of gas flow is beneficial due to the improved mixing of gases in the reactor and, importantly, allows for extension of the time of remaining the tiniest fuel grains through their flow towards the $\mathbf{C} \mathbf{1}$ chamber. This allows for a substantial limitation of the steam of fuel, which, with the molten slag, could flow to the $\mathbf{C 6}$ and $\mathbf{C 7}$ chambers.

The selected results of computations of the gasification process in the presence of water steam (variant V2) are presented in Fig. 5. Distribution of temperature for $\mathbf{V 2}$ variant is similar to the distribution for V1 in chambers C1, C2, C3. Slightly higher temperatures are observed in the $\mathbf{C 4}$ and $\mathbf{C 5}$ chambers, 
resulting from the difference in the demand for heat at gasification in the presence of $\mathrm{CO}_{2}(8)$ and $\mathrm{H}_{2} \mathrm{O}(9)$.

- the Boudouard reaction

$$
\mathrm{C}_{(\mathrm{s})}+\mathrm{CO}_{2}=2 \mathrm{CO}+172 \mathrm{MJ} / \mathrm{kmol}
$$

- the water gas reaction

$$
\mathrm{C}_{(\mathrm{s})}+\mathrm{H}_{2} \mathrm{O}=\mathrm{CO}+\mathrm{H}_{2}+131 \mathrm{MJ} / \mathrm{kmol}
$$

Analysis of the distribution of $\mathrm{CO}$ concentration for V2 (Fig. 5b) reveals that the highest values of $\mathrm{CO}$ concentrations occur near the $\mathbf{C} \mathbf{2}$ chamber walls whereas the $\mathrm{CO}$ concentration decreases down the stream. Analysis of the $\mathrm{H}_{2}$ distribution (Fig. 5c) reveals a noticeable increase in $\mathrm{H}_{2}$ concentration near the walls of the $\mathbf{C} 3$ and $\mathbf{C 4}$ (places of $\mathrm{O}_{2} / \mathrm{H}_{2} \mathrm{O}$ mixture supply). a) $V_{x}[\mathrm{~m} / \mathrm{s}]$

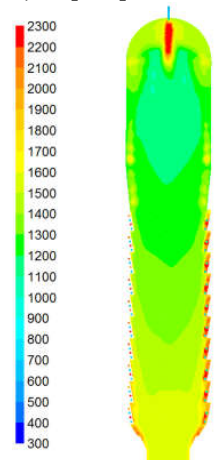

b) $\mathrm{CO}[-]$

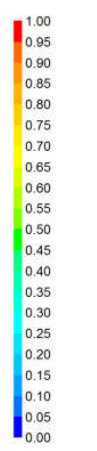

c) $\mathrm{H}_{2}[-]$

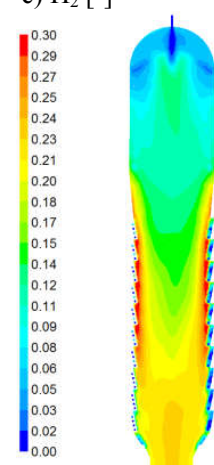

Fig. 5. Distribution of selected process values (V2): a) temperature distribution in the vertical cross-section, b) $\mathrm{CO}$ concentration, c) $\mathrm{H}_{2}$ concentration.

Table 2 compares composition of gases that leave the C5 chamber. It can be noticed that for the V1 variant, process gas is composed of $86 \% \mathrm{CO}$ and $5.65 \% \mathrm{H}_{2}$. In the case of $\mathbf{V 2}$ (gasification in the presence of water steam) the $\mathrm{CO}$ concentration reaches $68.5 \%$ whereas $\mathrm{H}_{2}$ concentration exceeds $21 \%$. Values of other gas components for both cases of V1 and V2 were similar.

Table 2. Selected process parameters at the outlet from $\mathbf{C 5}$ for coal dust gasification $(\mathbf{V 1}, \mathbf{V 2})$.

\begin{tabular}{|c|c|c|c|c|c|c|c|}
\hline Variant & $\begin{array}{c}\mathrm{CO} \\
{[\%]}\end{array}$ & $\begin{array}{c}\mathrm{H}_{2} \\
{[\%]}\end{array}$ & $\begin{array}{c}\mathrm{CO}_{2} \\
{[\%]}\end{array}$ & $\begin{array}{c}\mathrm{H}_{2} \mathrm{O} \\
{[\%]}\end{array}$ & $\begin{array}{c}\mathrm{VM} \\
{[\%]}\end{array}$ & $\begin{array}{c}\mathrm{O}_{2} \\
{[\%]}\end{array}$ & $\begin{array}{c}\mathrm{CH}_{4} \\
{[\%]}\end{array}$ \\
\hline $\mathbf{V 1}$ & 86.30 & 5.65 & 1.25 & 0.20 & 6.52 & $1.61 \mathrm{E}-04$ & $1.19 \mathrm{E}-05$ \\
\hline $\mathbf{V 2}$ & 68.67 & 21.37 & 1.52 & 2.58 & 5.84 & $1.39 \mathrm{E}-03$ & $1.35 \mathrm{E}-05$ \\
\hline
\end{tabular}

\section{Conclusions}

The concept and the design of coal dust gasification reactor presented in the study allows for performing the process of coal dust gasification in the atmosphere of $\mathrm{O}_{2} / \mathrm{CO}_{2}$ and $\mathrm{O}_{2} / \mathrm{H}_{2} \mathrm{O}$. Division of reactor into zones allows for controlling the gasification process. Process of fuel gasification is performed both in the central part of the reactor (the $\mathbf{C 2}$ chamber) and near its walls $(\mathbf{C 3}, \mathbf{C 4}$ chambers). Strong eddy motion of the fuel with the special design of the $\mathbf{C 4}$ chamber allows for intensification of the process of mixing between the fuel and gasification agent and extension of the time of fuel remaining in the reactor. The proposed solution also allows for ash vitrification in the lower part of the $\mathbf{C 4}$ chamber and in the $\mathbf{C 5}$ chamber. The computations of the fuel gasification process revealed opportunities to obtain the product containing $86.3 \% \mathrm{CO}$ and $5.6 \% \mathrm{H}_{2}$ for the V1 variant and $68.7 \% \mathrm{CO}$ and $21.4 \mathrm{H}_{2}$ for the $\mathbf{V 2}$ variant. These gases can be directly used for fuelling pulverized-fuel boilers in order to improve their flexibility, stabilization of the coal dust combustion process at low boiler loads and replacing the ignition burners during boiler start-up.

The gasification process in the atmosphere of $\mathrm{O}_{2} / \mathrm{CO}_{2}$ and $\mathrm{O}_{2} / \mathrm{H}_{2} \mathrm{O}$ allows for the control of temperature inside the reactor and separation of the processes of coal gasification and fly ash vitrification. With changes in the composition of the gasifying agent, it is possible to obtain a product (synthesis gas) with expected composition.

During designing and construction of new pulverized coal-fired boilers, they can be equipped in coal gasification reactors using the solution presented in this study. A compact design of the reactor allows for its installation near a pulverized coal-fired boiler. Using the coal dust as a fuel supplied to a coal gasification reactor allows for a substantial limitation of consumption of fuel oil or gas during operation of the pulverized coal-fired boiler. The design of the reactor should be integrated especially with pulverized coal-fired boilers where oxyfuel combustion processes are performed.

The installation of the coal gasification reactors in a pulverized coal-fired boiler system allows for:

- increasing the flexibility and dynamics of blocks with dust boilers,

- increase in thermal efficiency of boilers,

- reduction of the minimum technological operation of the dust boiler without the need to start the firing torches,

- implementation of the combustion and/or gasification process of solid fuels,

- carrying out the process of ash refining (e.g. during the period of cheaper night pricing).

The proposed solution constitutes an interesting technological option aimed at retrofitting and modernization of $200 \mathrm{MW}_{\mathrm{e}}$ class of dust mills.

\section{Acknowledgements}

Ministry of Science and Higher Education Republic of Poland BS/PB-404-301/11

\section{References}

1. R. Zarzycki, R. Kobyłecki, Z. Bis, Mechanic no 2, (2017)

2. Bis Z., Kotty fluidalne: teoria $i$ praktyka, (Wydawnictwo Politechniki Częstochowskiej, Częstochowa, 2010)

3. http://www.bine.info, Power plants with coal gasification, projekt info 09/06.

4. Borowiecki T., Kijeński J., Machnikowski J., Ściążko M., Czysta energia, produkty chemiczne $i$ paliwa $z$ wegla - ocena potencjatu rozwojowego, 
(Instytut Chemicznej Przeróbki Węgla, Zabrze, 2008)

5. Tomeczek J., Zgazowanie węgla (Skrypty centralne nr 1551/4, Politechnika Śląska, Gliwice, 1991)

6. A.J. Minchener, Fuel, vol. 84, (2005)

7. A.G. Collot, International Journal of coal Geology, vol. 65, (2016)

8. R. Zarzycki, R. Kobyłecki, M. Kratofil, Z. Bis, Energy Policy Journal, Tom 17, zeszyt 4, (2014)

9. Higman C., Van Der Burgt M., Gasification, (Elsevier Science, USA, 2003)

10. R. Zarzycki, Z. Bis, Journal of Thermal Science, Volume 26, Issue 2, (2017)

11. R. Zarzycki, Z. Bis, R. Kobyłecki, Procedia Engineering, Vol.157, (2016)

12. R. Zarzycki, Z. Bis, Procedia Engineering, Vol.157, (2016)

13. R. Zarzycki, Z. Bis, 12 th International Conference on Fluidized Bed Technology, (2017)

14. R. Zarzycki, Z. Bis, E3S Web of Conferences 13, 05003, (2017)

15. R. Zarzycki, E3S Web of Conferences 13, 05004, (2017)

16. R. Zarzycki, 12 th International Conference on Fluidized Bed Technology, (2017)

17. L. Chen, M. Gazzino, A.F. Ghoniem, 35th International Technical Conference on Coal Utilization \& Fuel Systems. Clearwater, Florida, (2010)

18. D. Toporov, P. Bocian, P. Heil, A. Kellermann, H. Stadler, S. Tschunko, M. Förster, R. Kneer, , Combustion and Flame, vol. 155, (2008)

19. M. Vascellari, G. Cau, Proceeding of CCT2009 Fourth International Conference on Clean Coal Technologies. Dresden, Germany, (2009)

20. P. Warzecha, A. Bogusławski, Archivum Combustionis, Vol. 12, nr 3, (2012)

21. R. Zarzycki, M. Kratofil, D. Pawłowski, M. Ścisłowska, R. Kobyłecki, Z. Bis, Energy Policy Journal, Tom 16, zeszyt 3, (2013)

22. ANSYS Fluent Theory Guide, (2011) 